\title{
Liberal Constitutionalism and the Unsettling of the Secular
}

\author{
Benjamin Berger \\ Osgoode Hall Law School of York University, bberger@osgoode.yorku.ca
}

\section{Source Publication:}

Rex Adhar, ed., Research Handbook on Law and Religion (Northampton, Mass: Edward Elgar, 2018), 198-220.

Follow this and additional works at: https://digitalcommons.osgoode.yorku.ca/scholarly_works

Part of the Religion Law Commons

\section{Repository Citation}

Berger, Benjamin, "Liberal Constitutionalism and the Unsettling of the Secular" (2018). Articles \& Book Chapters. 2747.

https://digitalcommons.osgoode.yorku.ca/scholarly_works/2747

This Book Chapter is brought to you for free and open access by the Faculty Scholarship at Osgoode Digital Commons. It has been accepted for inclusion in Articles \& Book Chapters by an authorized administrator of Osgoode Digital Commons. 


\title{
Liberal Constitutionalism and the Unsettling of the Secular
}

\author{
Benjamin L Berger*
}

\section{INTRODUCTION}

Our constitutional theories are constructed on a foundation of prior claims about the character of the social world. These foundational social understandings lend support and offer resources to the constitutional ideas and practices that they undergird. Indeed, they serve as the implicit conditions of plausibility for the accounts that we give about the nature and operation of constitutionalism and what we ask constitutional law to achieve. When elements of that substructure of assumptions or claims about the social world are unsettled or disrupted, gaps, cracks, and frailties in the constitutional superstructure are exposed. This relationship can be examined from either direction. Becoming alive to inconsistencies, trouble spots, or new perplexities in constitutional practice and theory, we might be moved to ask what has changed about the social facts - or our awareness of them - that otherwise lend coherence and stability to those theories and practices. Or seized with new or different understandings of, or newly aware of different facts about, the social world, we might wonder

\footnotetext{
${ }^{*}$ I benefitted greatly from conversations with Joel Bakan, Kate Glover, Martin Krygier, Lorne Sossin, and Jacob Weinrib as I worked through the ideas in this piece, and I am grateful to them for their insight and generosity. I wish also to thank Jamie Shilton for his superb research assistance.
} 
Forthcoming in Rex Adhar, ed., Research Handbook on Law and Religion (Northampton, Mass: Edward Elgar, 2018) (Pre-publication Version)

what impact this has on the stability and coherence of our approach to constitutional law.

And so, for example, a prior assumption about relative income equality or economic opportunity makes more plausible a certain set of claims about the role and nature of constitutional law. A more traditionally liberal approach to constitutions and constitutional rights sits more or less comfortably on that foundation, and a neo-liberal constitutionalism might thrive on it, approaching constitutionalism as a regulatory device in service of a promising free market. ${ }^{1}$ Our attention turned to homelessness, poverty, and radical income inequality, gaps open up in those accounts and practices. The absence of social and economic rights in a constitutional order now appears as a fundamental gap, not merely a question of institutional competence and a requirement for state action, ${ }^{2}$ and we will be more inclined to think about liberal constitutions as devices of wealth and property protection.

In this chapter, I suggest that certain features of our constitutional theories and practices have been more dependent than we have heretofore acknowledged on an implicit faith in the character and success of secularism. In particular, I have in mind what we might call a 'folk' ${ }^{3}$ understanding of secularism: one that imagines a more or less workable divide between religion and law/politics and that maps something like a general reduction in the public salience of religious belief, belonging, and practice. Reflection on modern constitutional practice has proceeded rather comfortably on an imaginative foundation in which some such understanding of secularism has been part of the furniture of the modern political and social order. In this respect, liberal constitutional theory has

\footnotetext{
${ }^{1}$ See Bernard E Harcourt, The Illusion of Free Markets: Punishment and the Myth of Natural Order (Cambridge, MA, Harvard University Press, 2011).

${ }^{2}$ See Gavin W Anderson, 'Social Democracy and the Limits of Rights Constitutionalism' (2004) 17 CJLJ 31.

${ }^{3}$ I am drawing inspiration here from Sally Falk Moore's classic description of a 'folk' understanding of law as a procedural tool at the disposal of states to achieve functional ends. Sally Falk Moore, Law as Process: An Anthropological Approach (London, Routledge \& Kegan Paul, 1978).
} 
Forthcoming in Rex Adhar, ed., Research Handbook on Law and Religion (Northampton, Mass: Edward Elgar, 2018) (Pre-publication Version)

simply participated in the common sense of most modern social and political reflection, in which

[t]he separation of the state and of its various institutions, including law, from religion, and with this the religious neutrality of the state (and the political neutering of religion), has been conceived as not only central to the emergence of this new order, but also necessary for its preservation and for the achievement of the justice that it is supposed to guarantee. ${ }^{4}$

This underlying assumption about the secular character of the social world has lent certain resources to liberal constitutional theory and made possible particular ideas about the nature of our constitutional lives, laws, and practices.

And yet the character - indeed, the existence - of this secularism has come into question. The conviction that our political and social lives can be satisfyingly described by that 'folk' account of secularism has been seriously destabilized by experience and theory alike. It turns out that the facts surrounding our social lives elude and exceed the containers relied upon by this understanding of secularism, and scholars have shown that secularism is a much more complex, untidy, and inconvenient concept. The best understanding of secularism is a matter of significant debate; that we are now denied a simple or stable concept of secularism on which to lean is not.

The question at the heart of this chapter is the following: What happens when we fold this emergent awareness of the instability of secularism back into accounts of the character of constitutions, their legitimacy, and the nature of constitutional adjudication? ${ }^{5}$ In essence, I am

\footnotetext{
${ }^{4}$ Winnifred Fallers Sullivan, Robert Yelle and Mateo Taussig-Rubbo, 'Introduction' in Winnifred Fallers Sullivan, Robert Yelle and Mateo Taussig-Rubbo (eds), After Secular Law (Stanford, Stanford Law Books, 2011) 1.

${ }^{5}$ Recent scholarship has generated a more complicated relationship between religion and law, showing ways in which the religious and the legal are far messier and less distinct. See eg Sullivan et al., After Secular Law. For example, the political theology literature has troubled the relationship between religion and the rule of law, writ large, as have historical accounts of the emergence of modern law. See, eg, Paul W Kahn, Political Theology: Four New Chapters on the Concept of Sovereignty (New York, Columbia University Press, 2011); James Q Whitman, The
} 
Forthcoming in Rex Adhar, ed., Research Handbook on Law and Religion (Northampton, Mass: Edward Elgar, 2018) (Pre-publication Version)

asking whether the success of central aspects of contemporary constitutional theory and practice is tethered to the fate of a certain understanding of the secular. The stresses of religious difference that have disturbed confidence in sociological and political claims about the character and demands of secularism may lead us to question our comfort with the orthodoxies - and unsettle certain idées fixes - of contemporary liberal constitutionalism. Faith in the secular character of the social world - understood in a particular way - has afforded certain analytical resources for constitutional law and possibilities for how we might understand contemporary constitutionalism. Denied those possibilities and resources, we see certain gaps or shortcomings in prevailing accounts of liberal constitutionalism. In particular, and drawing heavily from the Canadian example, this chapter explores the way in which the facts associated with this unsettling of secularism trouble theories that position proportionality as the central feature of modern constitutional life, challenge the centrality of rights constitutionalism in constitutional thought and practice, and ultimately raise questions about the ground for constitutional authority and legitimacy, pointing to the abiding salience of claims about sovereignty in modern constitutionalism. Put under pressure by the social facts surrounding religion and politics, as this part of the foundation unsteadies and begins to shake, vulnerabilities and deficiencies in our constitutional theory are revealed.

To be clear, the claim is not that the social facts surrounding religion, law, and politics are responsible for generating or producing those faults or shortcomings, as though but for an instability in secularism, the edifice would be solid and sound. Rather, these faults are latent in the architecture (in the assumptions and ideology) of liberal constitutional theory and practice, and are simply exposed by tracing the effects of a disruption in the secular. As I alluded to at the outset of this chapter, other shifts in our understanding of the social world are eminently capable of doing similar diagnostic work. But it is true that religion seems particularly adept at, if not uniquely able to, trouble the conceits of liberal

Origins of Reasonable Doubt: Theological Roots of the Criminal Trial (New Haven, Yale University Press, 2008). 
Forthcoming in Rex Adhar, ed., Research Handbook on Law and Religion (Northampton, Mass: Edward Elgar, 2018) (Pre-publication Version)

constitutionalism. It is, therefore, to the unsettling of the 'folk' idea of secularism that I now turn.

\section{THE UNSETTLING OF SECULARISM}

Over the past many years, the concept of the secular has been under siege by social and political theorists and philosophers who have contested its meaning, history, and character, exploring both the range of social and political phenomena that 'secularism' can describe, and the political ends that it can serve. José Casanova, for example, famously distinguished between secularism as a claim about the overall reduction in religious adherence in society and secularism as designating a privatization of religion. ${ }^{6}$ Years later, in his conceptual history of the secular, A Secular Age, Charles Taylor added a third way of understanding secularism to this definitional mix. Secularism, for Taylor, centrally describes an imaginative shift in which religion and a religious life slowly became but one option among others for a life of human flourishing- his so-called 'secularism $3^{\prime} .7$

These kinds of definitional debates have been accompanied by a growing awareness of the diverse range of political configurations that can subsist under the capacious umbrella of the term 'secularism'. The contrasting archetypes of French laïcité and American free exercise or Anglo-multiculturalism (themselves misleading as to the forms of religious and political life lived in those countries) ${ }^{8}$ have featured prominently in commentary about the nature and demands of the secular. In a pivotal moment in debates about the management of religious diversity in Canada, Gérard Bouchard and Charles Taylor labelled these

\footnotetext{
${ }^{6}$ José Casanova, Public Religions in the Modern World (Chicago, University of Chicago Press, 1994).

${ }^{7}$ Charles Taylor, A Secular Age (Cambridge, MA, Belknap Press, 2007).

${ }^{8}$ John R Bowen, Can Islam Be French? Pluralism and Pragmatism in a Secularist State (Princeton, Princeton University Press, 2009).
} 
Forthcoming in Rex Adhar, ed., Research Handbook on Law and Religion (Northampton, Mass: Edward Elgar, 2018) (Pre-publication Version)

competing models 'closed' and 'open' secularism, ${ }^{9}$ whereas Tariq Modood prefers to describe these main historical strands as 'radical' and 'moderate' secularism. ${ }^{10}$

Yet the pluralization of secularism goes well beyond two archetypal models. Scholars point to the diverse and varied local practices and settlements collected within these two broad categories, as well as wholly different ways of structuring the relationship between state power and religion, leaving us with 'varieties of secularisms', rather than a single concept of the secular. ${ }^{11}$ The variety of forms of the secular, and the various relationships between religion and state institutions that the concept seems to embrace, is such that it seems dangerous to claim that 'secularism' demands much of anything in particular. ${ }^{12}$

And so a deep indeterminacy has settled in around the concept of the secular, to the extent that it seeks to offer or describe a specific regulatory ideal for how to keep the state and its authority and institutions separate from religion. Indeed, if it points to something, it may be that 'secularism' marks the involvement of the state in matters of religion, not their insulation from one another. This is Talal Asad's claim, pointing as he does to the way in which secularism bears the imprint of its historical formation in contact with Christianity and is still, in fact, defined by its

\footnotetext{
${ }^{9}$ Quebec, Commission de consultation sur les pratiques d'accomodement reliées aux différences culturelles, Building the Future: A Time for Reconciliation, by Gérard Bouchard and Charles Taylor (Quebec City, Gouvernement du Québec, 2008).

10 Tariq Modood, 'Is There a Crisis of Secularism in Western Europe?' (2012) 73 Sociology of Religion 130.

11 Janet R Jakobsen and Ann Pellegrini (eds), Secularisms (Durham, NC, Duke University Press, 2008). Rajeev Bhargava points to India as a source for a model of secularism built on ideas of 'principled distance' and 'contextual secularism': 'States, Religious Diversity, and the Crisis of Secularism’ (2010) 10 The Hedgehog Review 8.

${ }^{12}$ I discuss this problem of being caught between the particular and the universal in claims about the character of the secular in Benjamin L Berger, 'Belonging to Law: Religious Difference, Secularism, and the Conditions of Civic Inclusion' (2015) 24 Social \& Legal Studies 47. More generally, I discuss the risks - both conceptual and material - inherent in the legal use of the concept of the secular in Benjamin L Berger, Law's Religion: Religious Difference and the Claims of Constitutionalism (Toronto, University of Toronto Press, 2015).
} 
Forthcoming in Rex Adhar, ed., Research Handbook on Law and Religion (Northampton, Mass: Edward Elgar, 2018) (Pre-publication Version)

relationship with and involvement in religion. ${ }^{13}$ And it is Agrama's essential claim when he explains that '[i]t is secularism itself that incessantly blurs together religion and politics in Egypt'. ${ }^{14}$ Secularism, for Agrama, is not a determinate concept or institutional configuration but, rather, a 'problem-space' that draws the state into asking and seeking to answer questions about religion. Marching under the banner of 'secularism', state institutions must ask and answer questions about the nature and definition of religion, about the meaning of religious symbols and practices, and about the location of the boundary between religion and state. 'Thus', he explains, 'what best characterizes secularism is not a separation between religion and politics, but an ongoing, deepening entanglement in the question of religion and politics, for the purpose of identifying and securing fundamental liberal rights and freedoms' ${ }^{\prime 15}$

Meanwhile, alongside this growing conceptual instability around the idea of the secular, we have watched as social facts have belied the folk conception of what modern secularity entails. Religion is simply more muscularly present, more persistently assertive, in 'secular' states than this understanding allows or than the so-called 'secularization thesis' - the idea that, within modernity, religion and religiosity would experience steady decline - predicted. There has been a kind of renewed awareness - or rediscovery - of the public salience of religion. Bhargava argues that, in this sense, secularism is a concept very much under strain. He goes so far as to describe this as a perceived 'crisis' of secularism and explains that, to a considerable extent, the pressure exerted on the descriptive account of an increasingly non-religious political world is a result of migration and the growing presence of Muslims in Europe. As Bhargava explains, 'the crisis of secular states in Europe is due, in part, because the secular humanist ethos endorsed by many citizens is not fully shared, particularly

\footnotetext{
${ }^{13}$ See eg Talal Asad, Formations of the Secular: Christianity, Islam, Modernity (Stanford: Stanford University Press, 2003); Talal Asad, 'French Secularism and the "Islamic Veil Affair", (2003) 8 The Hedgehog Review 93.

${ }^{14}$ Hussein Ali Agrama, 'Sovereign Power and Secular Indeterminacy: Is Egypt a Secular or a Religious State?' in Winnifred Fallers Sullivan, Robert Yelle and Mateo Taussig-Rubbo (eds), After Secular Law (Stanford, Stanford University Press, 2011) ch 9, 184.

${ }^{15}$ Ibid, 186.
} 
Forthcoming in Rex Adhar, ed., Research Handbook on Law and Religion (Northampton, Mass: Edward Elgar, 2018) (Pre-publication Version)

by those who have newly acquired citizenship'. ${ }^{16}$ Though he is writing of Europe, similar trends are evident in North America and elsewhere in the world. ${ }^{17}$ Bhargava sums up the character and source of this 'crisis of secularism' as the 'new reality of the vibrant presence of multiple religions in public life and the accompanying social tensions'.18

Modood argues that to claim that there is a 'crisis of secularism' in Europe 'is not only exaggerated but misleading'. ${ }^{19}$ For him, ' $[\mathrm{t}]$ he 'crisis of secularism' is really the challenge of multiculturalism'. ${ }^{20}$ And yet he nevertheless agrees that '[p]olitical secularism has been destabilized, in particular the historical flow from a moderate to radical secularism and the expectation of its continuation has been jolted'. ${ }^{21}$ Modood explains that, with the demographic and social changes associated with deeper religious diversity, 'it slowly becomes apparent that the secularist status quo, with certain residual privileges for Christians, is untenable as it stands'.22

But of course, the energetic persistence of religion in public life is far from exclusively a matter of increased religious difference born of demographic change, immigration, or the political presence of Islam. Canvassing the case law and scholarship around the world, one sees that the disruption of the expected historical flow toward the more thorough separation of religion and public life that Modood describes - what he calls the destabilization of political secularism - is also a product of assertive expressions of Christianity in political policies, social life, and legal debates. ${ }^{23}$ This, too, is a significant source of the 'vibrant presence of

\footnotetext{
${ }^{16}$ Bhargava, 'Crisis of Secularism', 11.

${ }^{17}$ Anuradha Dingwaney Needham and Rajeswari Sunder Rajan (eds), The Crisis of Secularism in India (Durham, NC, Duke University Press, 2007).

${ }^{18}$ Bhargava, 'Crisis of Secularism', 12.

${ }^{19}$ Modood, 'Western Europe', 146.

${ }^{20}$ Ibid.

${ }^{21}$ Ibid, 145.

22 Ibid.

${ }^{23}$ See, eg, Bethany Moreton, To Serve God and Wal-Mart: The Making of Christian Free Enterprise (Cambridge, MA, Harvard University Press, 2009); Winnifred Fallers Sullivan, Prison Religion: Faith-Based Reform and the Constitution (Princeton, Princeton University
} 
Forthcoming in Rex Adhar, ed., Research Handbook on Law and Religion (Northampton, Mass: Edward Elgar, 2018) (Pre-publication Version)

multiple religions in public life and the accompanying social tensions' ${ }^{24}$ In short, as we look around our social world, the folk account of 'secularism' seems simply not to describe what we see. Religion has not retreated into the private realm, withdrawing from the domain of politics and law, nor does it appear to be poised to do so.

Tested, questioned, and challenged by these historical, philosophical, and sociological observations, an understanding of the modern state as 'secular' has been seriously unsettled. It fails to satisfyingly capture what we see happening in our social and political lives, and, with its range of meanings and encoded partiality, no longer seems to offer itself as a response to or a tool for managing religious difference. Reveries of secularism seem to have been disturbed by inconvenient social and historical facts. And as the concept of secularism has become descriptively and normatively unstable, new questions are raised as to the character of the modern state that it sought to describe. Some have responded by describing the condition in contemporary western societies as, instead, 'post-secular'. ${ }^{25}$ Although this moniker has itself attracted a range of meanings and definitions, ${ }^{26}$ the term draws attention to the untidiness and complexity of the role of religion in modern society, '[highlighting] the active, even robust, presence of religion ... or, at the very least, the recognition of religious ideas as normatively "legitimate" and persuasive to many', ${ }^{27}$ as well as the deep normative diversity (referred to as the 'fragmentation of meaning' by some) ${ }^{28}$ that defines the contemporary condition.

Press, 2009); Elizabeth Shakman Hurd, Beyond Religious Freedom: The New Global Politics of Religion (Princeton, Princeton University Press, 2015).

${ }^{24}$ Bhargava, 'Crisis of Secularism', 12.

${ }^{25}$ See, eg, Jürgen Habermas, 'Notes on Post-Secular Society' (2008) 25 New Perspectives Quarterly 17. Arif Jamal offers a helpful and compendious description of the ideas that have collected around the term 'post-secular' in his 'Considering Freedom of Religion in a PostSecular Context: Hapless or Hopeful?' (2017) 6 Oxford J of Law \& Religion 433.

${ }^{26}$ James Beckford, 'SSSR Presidential Address - Public Religions and the Post-secular: Critical Reflections' (2012) 51 J for the Scientific Study of Religion 1.

${ }^{27}$ Jamal, 'Considering Freedom of Religion', 436.

${ }^{28}$ See Zachary R Calo, 'Religion, Human Rights, and Post-Secular Legal Theory' (2011) 85 St John's L Rev 495; Jamal, 'Considering Freedom of Religion', 436-7. 
Forthcoming in Rex Adhar, ed., Research Handbook on Law and Religion (Northampton, Mass: Edward Elgar, 2018) (Pre-publication Version)

This brings us to the question at the heart of this piece: how might this unsettling of secularism trouble contemporary constitutional theory and practice? What gaps, cracks, or shortcomings in prevailing accounts of liberal constitutionalism appear when they are denied the support of the stabilizing ideas associated with secularism?

\section{CONSEQUENCES FOR LIBERAL CONSTITUTIONALISM?}

A more or less stable, confident claim about secularism understood as the separation of religion from politics, law, and state institutions - offers certain resources to constitutional theory and practice. It puts pieces in play to be relied upon when developing our understandings of constitutional law and practice. There is, for example, a vision of the good citizen implied by concepts of the secular: someone who can understand religion as a discrete and therefore manageable component of their lives; someone thereby fitted to a sense of the social and political in which the private/public divide is an organizing principle; someone whose interests and concerns are largely immanent. Similarly, as I will explore below, the ability to invoke a claim about the secular provides access to a form of normative authority that is based on the adequacy of reasons and the success of the state's reason-giving - an understanding of legitimacy grounded on consensus and convergence, and one that does not depend on resort to larger metaphysical or ontological claims. These are but examples of the kinds of imaginative resources that constitutional law gains by having a claim about secularism that is felt to faithfully map the social world over which law presides. But as secularism becomes unstable, these pieces are pulled away. We begin to see that elements of the liberal constitutional common sense are themselves unsteady. And what ensues is an awareness of the inadequacy of central aspects of orthodox accounts of the character of modern liberal constitutionalism.

In what follows, I take up certain of those core elements and, drawing heavily from the Canadian example, explore the way in which they are disrupted by a social world that resists the claims of secularism, ultimately arriving at an examination of the challenges posed for how we understand the sources of constitutional legitimacy and authority. 
Forthcoming in Rex Adhar, ed., Research Handbook on Law and Religion (Northampton, Mass: Edward Elgar, 2018) (Pre-publication Version)

Proportionality as the 'Ultimate Rule of Law' and the Key Task of 'the Judge in a Democracy'

The ascendancy of proportionality as the defining characteristic of modern liberal constitutionalism is a well-observed phenomenon. ${ }^{29}$ Proportionality is the elephant in the comparative constitutionalist's room. Despite persistent divergence in varieties of substantive constitutional particulars, the idea that the essence of modern constitutionalism both can and should be found in the logic of proportionality is a prized orthodoxy. Proportionality has settled into the heart of Canadian constitutional life, becoming central to how the just constitutional state is imagined. Gaining an early foothold in the means-ends balancing test involved in the justificatory clause of the Canadian Charter of Rights and Freedoms, s 1,30 the ethic or logic of proportionality has metastasized through its absorption into administrative law, now measuring the justice of all state decision-making. ${ }^{31}$ But the Canadian iteration of proportionality is hardly distinctive; it is an echo of the necessity and suitability conditions found in the jurisprudence of the German Federal Constitutional Court, has drawn inspiration from Israeli understandings and experience of proportionality

\footnotetext{
${ }^{29}$ See Paul W Kahn, 'Comparative Constitutionalism in a New Key' (2003) 101 Michigan L Rev 2677; Alec Stone Sweet and Jud Mathews, 'Proportionality Balancing and Global Constitutionalism' (2008) 47 Colum J Transnat'l L 72; Grégoire CN Webber, 'Proportionality, Balancing, and the Cult of Constitutional Rights Scholarship' (2010) 23 CJLJ 179; Benjamin L Berger, 'The Abiding Presence of Conscience: Criminal Justice Against the Law and the Modern Constitutional Imagination' (2011) 61 U Toronto LJ 579; Jacob Weinrib, Dimensions of Dignity: The Theory and Practice of Modern Constitutional Law (Cambridge, Cambridge University Press, 2016).

${ }^{30}$ Canadian Charter of Rights and Freedoms, Part I of the Constitution Act, 1982, being Schedule B to the Canada Act 1982 (UK), 1982, c 11. This proportionality test, governing the analysis of s 1, was established in $R v$ Oakes, [1986] 1 SCR 103.

${ }^{31}$ Doré v Barreau du Québec, 2012 SCC 12. This expansion in the role of proportionality is an interesting dramatization of Alexy's theory of horizontal effect (Robert Alexy, A Theory of Constitutional Rights (transl Julian Rivers; Oxford, Oxford University Press, 2002) 352ff), whereby, as Kumm puts it, '[c]onstitutional rights norms 'radiate' into all areas of the legal system ... so as to affect the rights and duties of all actors within the jurisdiction' (Mattias Kumm, 'Constitutional Rights as Principles: On the Structure and Domain of Constitutional Justice’ (2003) 2 ICON 574, 585.)
} 
Forthcoming in Rex Adhar, ed., Research Handbook on Law and Religion (Northampton, Mass: Edward Elgar, 2018) (Pre-publication Version)

review, ${ }^{32}$ and is reflective of a global common sense about the essential character of constitutionalism. ${ }^{33}$ Proportionality has been described both as the central practice of constitutional adjudication (the key task of 'the judge in a democracy' ${ }^{34}$ ) and the governing measure of constitutional justice, or the 'ultimate rule of law'. 35

If one looks under the hood of proportionality, one sees that it 'is nothing more than the contemporary expression of reasonableness' ${ }^{36}$ As an account of modern constitutionalism, it rests on a particular way of imagining the relationship between reason and state justice. Paul Kahn makes this point when he describes the genealogy of proportionality review, which, he claims, 'lies in the belief that the rule of law is the internalization of reason itself as a regulative ideal within the political order' ${ }^{\prime}{ }^{37}$ That which is constitutional is that which is reasonable, all things considered. For those who advance this account of the character of constitutionalism, it is a means of imagining constitutional judgment that 'permits disputes about the limits of legitimate lawmaking to be settled on the basis of reason and rational argument' ${ }^{38}$ As one scholar describes it, this means that proportionality can 'claim an objectivity and integrity no

\footnotetext{
${ }^{32}$ In Alberta v Hutterian Brethren of Wilson Colony, 2009 SCC 37, the Supreme Court of Canada cited and drew from Aharon Barak, 'Proportional Effect: The Israeli Experience' (2007) $57 \mathrm{U}$ Toronto LJ 369.

${ }^{33}$ See Weinrib, Dimensions of Dignity, 215-6.

${ }^{34}$ Aharon Barak, The Judge in a Democracy (Princeton: Princeton University Press, 2006).

${ }^{35}$ David M Beatty, The Ultimate Rule of Law (Oxford, Oxford University Press, 2004). There is a rich literature debating the merits, and offering various models, of proportionality review. The purpose of the present discussion is not to rehearse and explore those extensive debates. For an excellent review of these debates, and for a sophisticated conception of the 'moral structure of proportionality', see Weinrib, Dimensions of Dignity, 215-271. For criticisms of proportionality review see eg Grégoire CN Webber, The Negotiable Constitution: On the Limitation of Rights (Cambridge, Cambridge University Press, 2009); Webber, 'Cult of Constitutional Rights Scholarship'; Francisco J Urbina, A Critique of Proportionality and Balancing (Cambridge, Cambridge University Press, 2017).

${ }^{36}$ Kahn, 'Comparative Constitutionalism', 2698.

${ }^{37}$ Ibid.

${ }^{38}$ Beatty, The Ultimate Rule of Law, 42.
} 
Forthcoming in Rex Adhar, ed., Research Handbook on Law and Religion (Northampton, Mass: Edward Elgar, 2018) (Pre-publication Version)

other model of judicial review can match' ${ }^{39}$ Proportionality's elevation of reasonableness as the core logic of constitutional justice thus takes its force and appeal in large measure from its imagined ability to suppress its alternative - the presence of interest, identity, will, and the political in constitutional judgment.

Yet how dependent has this picture of constitutionalism defined by proportionality been on the success of claims about secularism? The perduring and vital presence of religion in the public sphere troubles this account of proportionality as the multi-tool fitted to questions of constitutional justice. It does so, first, by challenging the adequacy of the methods of proportionality reasoning in dealing with issues related to religion and religious rights. Theorists have articulated different models of how proportionality reasoning works. In some understandings, proportionality involves a direct balancing of competing rights and principles. ${ }^{40}$ For others, the competing principles are instead measured against some 'common yardstick' 41 or by reference to the extent that each advances an underlying norm. ${ }^{42}$ In either understanding, however, when religion is involved there must be some assessment of the constitutional 'good' of religion and the extent to which it is implicated in the given case.

And yet it turns out that we are unsure how to measure and weigh religion for the purposes of constitutional analysis. ${ }^{43}$ To do so requires generating a theory of the constitutional value of religion and, as scholarly

\footnotetext{
${ }^{39}$ Ibid, 171.

${ }^{40}$ This is Alexy's model as reflected in his 'Law of Balancing'. See Alexy, A Theory of Constitutional Rights.

${ }^{41}$ Stone Sweet and Mathews, 'Proportionality Balancing', 105.

${ }^{42}$ This is, for example, Weinrib's conception, in which 'the yardstick against which these quantities are set is the ideal of public justice or human dignity under law': Weinrib, Dimensions of Dignity, 229. For Weinrib, this means that '[p]roportionality reflects the absolute duty of government to bring the existing legal order into the deepest possible conformity with human dignity'. Ibid, 240.

${ }^{43}$ Others have noted the problematic character of this exercise of assigning weight to constitutional interests, making the point by reference to other constitutional rights and interests; the discussion often revolves around the problem of 'incommensurability' in constitutional proportionality reasoning. See, eg, Urbina, A Critique of Proportionality; Webber, The Negotiable Constitution. Again, my claim is not that religion is unique in raising this problem, even if it is uniquely good at doing so.
} 
Forthcoming in Rex Adhar, ed., Research Handbook on Law and Religion (Northampton, Mass: Edward Elgar, 2018) (Pre-publication Version)

debates have shown, we are not equipped with a clear sense of what it is about religion that attracts our constitutional regard. ${ }^{44}$ Moreover, effective proportionality review in matters of religion would also seem to require descending into the spiritual infrastructure of an individual or community's life - something to which liberal constitutionalism is allergic, not to mention ill-equipped to do - in order to assign a 'gravity' to the state's interference with a religious practice or belief. One sees here how much proportionality, as an account of the heart of liberal constitutionalism, depends on an assumption about 'the progressive immanence of our concerns and our references'. ${ }^{45}$ Proportionality may work more or less well for the weighing of immanent concerns; however, the unsettling of secularism denies us confidence that the nature of the interests and preoccupations of those who come before the courts have that immanent quality.

As a result, we find cases in which proportionality seems to founder as means of assessing the constitutionally just. In Canada, one thinks of the Hutterian Brethren of Wilson Colony case, in which the Supreme Court was called upon to assess whether a government requirement for photographs on drivers' licences was a proportional limit on the religious freedoms of an insular agrarian Hutterite community whose interpretation of the second commandment translated into a prohibition on having one's photograph taken. Drawn into the proportionality analysis that is the heart of Canadian constitutional adjudication, the majority of the Court explained that the burden on the members of Wilson Colony was best characterized in terms of costs - 'costs on the religious practitioner in terms of money, tradition or inconvenience' 46 - and that those costs were relatively trivial in comparison to the state interest in a secure photo

\footnotetext{
${ }^{44}$ For an excellent recent treatment of this problem, see Jamal, 'Considering Freedom of Religion'. For an example of a debate driven by the indeterminacy about the 'good' protected by religion in liberal constitutions, see Christopher L Eisgruber and Lawrence G Sager, Religious Freedom and the Constitution (Cambridge, MA, Harvard University Press, 2007); Jeremy Webber, 'Understanding the Religion in Freedom of Religion' in Peter Cane, Carolyn Evans and Zoe Robinson (eds), Law and Religion in Theoretical and Historical Context (Cambridge, Cambridge University Press, 2008) 26.

${ }^{45}$ Sullivan et al., 'Introduction', 1 .

${ }^{46}$ Wilson Colony, [95].
} 
Forthcoming in Rex Adhar, ed., Research Handbook on Law and Religion (Northampton, Mass: Edward Elgar, 2018) (Pre-publication Version)

licensing scheme. Many have critiqued this decision as failing to capture what was at stake for the religious community. ${ }^{47}$ To be sure, the assessment could have been performed better and more sensitively; and, indeed, the dissenting judgment written by Justice Abella did a far better job of accounting for the impacts of the photo requirement on the life of the community. And yet, for the reasons I have described, the ability to weigh religion seems always out of reach, pointing to a weakness in proportionality as an analytic tool in arriving at constitutional justice. ${ }^{48}$

The point is well made by the facts of another Canadian case, $A C .49$ The question here was whether the religious freedom right of a 15-yearold Jehovah's Witness entitled her to refuse a life-saving blood transfusion. The majority of the Court avoided the core constitutional question, relying instead on an admixture of statutory interpretation and future exercises of discretion. The evasion was understandable. What would a proportionality analysis that gave sensitive regard to the religious interests in the case look like? It would have to wrestle with the subject's transcendent and metaphysical concerns - the immortal life of her soul and weigh that against the state's interest in the preservation of life. Again, proportionality review as a measure of the just seems to stumble over the questions raised by religion as an assertive and insistent part of our social worlds. Something more or different is needed to meet the judgmental burdens imposed by such questions.

\footnotetext{
${ }^{47}$ For my criticisms, see Benjamin L Berger, 'Section 1, Constitutional Reasoning, and Cultural Difference: Assessing the Impacts of Alberta v Hutterian Brethren of Wilson Colony' (2010) 51 Sup Ct L Rev (2d) 25.

${ }^{48}$ In this vein, Kai Möller, critical of Alexy's approach, suggests that dealing with constitutional rights will inevitably involve moral arguments, not simply proportionality review. See Kai Möller, 'Balancing and the Structure of Constitutional Rights' (2007) 5 ICON 453. It might be that other models or accounts of proportionality, in particular those that embrace a normative view of the balancing involved could fare better (see eg Weinrib, Dimensions of Dignity, arguing that balancing should occur in reference to 'human dignity', and Barak, The Judge in a Democracy, structuring his account of balancing around 'society's values'). Nevertheless, the specific issues that I have described as associated with the constitutional adjudication of religion - understanding why we protect religion, the need to engage with the spiritual infrastructure of religious lives, and how these impact on the weighing or balancing of religion - still pose a challenge to these models.

${ }^{49}$ AC v Manitoba (Director of Child and Family Services), 2009 SCC 30.
} 
Forthcoming in Rex Adhar, ed., Research Handbook on Law and Religion (Northampton, Mass: Edward Elgar, 2018) (Pre-publication Version)

Yet, beyond questioning its internal adequacy as a tool, the instability of the secular also seems to unsettle the descriptive claim that, in modern liberal constitutionalism, proportionality review is the key task or the principal business of a judge in a democracy. The wish that this were so is understandable enough. Proportionality's foundation in formal reason rescues the liberal constitutional judge from the messiness of history, identity, symbolic interpretation, and the like. Describing constitutional adjudication in terms of proportionality places the legitimacy of judicial review on somewhat safer ground. Yet it turns out that, faced with publicly assertive forms of religion and the associated exposure of the residual privilege enjoyed by the religions around whom the secular status quo was formed, judges in democracies have often instead been preoccupied with the task of symbolic interpretation and identity construction. And those are tasks that emphatically raise the basic questions at the heart of debates on the legitimacy of judicial review: to borrow from Joel Bakan's excellent distillation, why should we trust judges' decisions on those kinds of issues and why would we think that they are more likely to arrive at truth on such matters? ${ }^{50}$ Balancing and proportionality have been part of the picture, to be sure. However, a glance at the cases about religion that have found their way to constitutional courts puts proportionality in its place as but one piece - and arguably not the most significant - of what constitutional adjudication involves.

In Canada, a recent case concerning prayer at a municipal council, Saguenay, 51 makes the point well. At issue was whether the practice of beginning municipal council meetings in the town of Saguenay, Québec, with a palpably Christian (and, specifically, Roman Catholic) prayer following which those who did not wish to be present for the prayer could enter the council chamber - offended the freedom of religion and conscience of non-believers. Concluding that this practice was unconstitutional, the Supreme Court leaned on the concept of state neutrality and explained the exclusionary communicative effects of this public prayer. Given the complicated history of Catholicism in the

\footnotetext{
${ }^{50}$ Joel Bakan, Just Words: Constitutional Rights and Social Wrongs (Toronto, University of Toronto Press, 1997).

${ }^{51}$ Mouvement laïque québécois v Saguenay (City), 2015 SCC 16.
} 
Forthcoming in Rex Adhar, ed., Research Handbook on Law and Religion (Northampton, Mass: Edward Elgar, 2018) (Pre-publication Version)

province of Québec, the task of the Court was to interpret the character of this prayer (and prayer generally), assess it against the historical backdrop of religion in Québec, imagine the communicative effect on listeners, and make claims about the character of the modern state. Proportionality reasoning was a marginal aspect of the decision, with these symbolic, political, and historical claims featuring far more prominently.

The same lesson emerges as one looks at law and religion cases that have emerged elsewhere in the world. The nature and meaning of prayer was at the heart of the US Supreme Court's decision in Town of Greece $v$ Galloway, ${ }^{52}$ and in Elk Grove v Nedow ${ }^{53}$ the Court ruled on the reference to God in the pledge of allegiance, ultimately arguing that it represented a permissible form of 'ceremonial deism' that needed to be understood in the frame of American national history and identity. In the (in)famous case of Lautsi, the pivotal task for the European Court of Human Rights was defining the meaning of the crucifix on the walls of Italian classrooms, a task that required reconciling the demand for state neutrality with the role of Catholicism in shaping Italian national identity. ${ }^{54}$ That Court's burden in Sahin was to interpret the symbolic significance of the headscarf within the frame of Kemalism and the Islamic revival in Turkey. ${ }^{55}$ And in JFS, ${ }^{56}$ the UK Supreme Court was called upon to rule as to whether 'Jewishness' was a religious or ethnic feature.

These are the kinds of cases that reflect the social facts and pressures associated with the unsettling of the secular. By the light of such cases, the assertion that proportionality analysis is the key task of a constitutional judge or the central measure of constitutional justice is somewhat mystifying. Rather than a balancing or the measuring of competing interests against a common normative yardstick, constitutional adjudication in matters of religion appears fundamentally as a symbolizing practice, one whereby the courts use law to make claims

\footnotetext{
52134 S Ct 1811 (2014).

${ }^{53}$ Elk Grove Unified School District v Newdow, 542 US 1 (2004).

${ }^{54}$ Lautsi v Italy (2011) 54 EHRR 3.

${ }^{55}$ Leyla Sahin v Turkey (2005) 44 EHRR 5.

${ }^{56} R$ (on the application of E) $v$ Governing Body of JFS [2009] UKSC 15.
} 
Forthcoming in Rex Adhar, ed., Research Handbook on Law and Religion (Northampton, Mass: Edward Elgar, 2018) (Pre-publication Version)

about national identity, history, and value. The status of proportionality as the grand idea of liberal constitutionalism thus seems seriously troubled by a social world that resists easy claims about secularism. It is troubled both in its capacity to carry off the tasks assigned to it and as a description of what modern constitutionalism demands of the judge. Perhaps it is only under the conceits of secularism that a scholar can boast of the universality of proportionality and claim that, '[o]n a shrinking planet, it is appropriately multicultural. ${ }^{.57}$

\section{The Centrality of Rights Constitutionalism}

It is commonplace to observe that the gaze of liberal constitutional thought has been principally focused on the individual and the character of the package of fundamental rights and freedoms to which she is entitled. Rights constitutionalism is imagined as both the core and the vanguard of modern constitutional thought and practice. This focus on rights-based protections as the heart of modern constitutionalism is, in fact, another expression of the ambition to universality at work in the veneration of proportionality. This is the constitutionalism that is reflected in Canada in the Charter of Rights and Freedoms, which now occupies the centre of public consciousness about what constitutionalism entails. It is the constitutionalism of the American Bill of Rights and of the package of 'universal declarations' that aspire to shape the project of European constitutionalism. Based, as it is, on more or less universal claims about the human and human flourishing, liberal rights constitutionalism offers itself as distinctively mobile, applicable to anyone, anywhere. This mobility allows for (indeed, invites) substantial borrowing across

\footnotetext{
${ }^{57}$ Beatty, The Ultimate Rule of Law, 168.
} 
Forthcoming in Rex Adhar, ed., Research Handbook on Law and Religion (Northampton, Mass: Edward Elgar, 2018) (Pre-publication Version)

constitutional traditions, 58 thereby facilitating the 'migration of constitutional ideas'.59

And yet there is an older - perhaps 'ancient' - idea of constitutions that is centrally concerned with the local, the political, the historically contingent, and 'harmonious relations between cultures' 60 and communities. This is the sense of constitutions as political devices aimed at working out local problems among particular interests in a given place. It reflects a different logic of constitutionalism, one concerned with the particular, rather than the universal.

Canada is manifestly a child of both logics. Its comparatively new Charter reflects the drive towards the universal; the much older features of the constitution that relate to the relationship between the French and English, its federal structure, and the relationship to Indigenous peoples, are all expressions of the particular. The insistent trend of modern constitutionalism has been to privilege the universal through emphasis on rights constitutionalism. And yet all constitutions are amalgams of both logics. ${ }^{61}$

As faith in the categories and conceits of the secular wanes, we are reminded of the importance - even, perhaps, the centrality - of that ancient idea of a constitution that is concerned with relationships among communities, sources of legal authority, and the structural issues of constitutional law and practice. To be sure, rights constitutionalism

\footnotetext{
${ }^{58}$ Ran Hirschl, Comparative Matters: The Renaissance of Comparative Constitutional Law (Oxford, Oxford University Press, 2014). Hirschl explains that constitutional courts engage in 'borrowing' with respect to rights issues far more than structural or formative dimensions of constitutional law.

${ }^{59}$ Sujit Choudhry (ed), The Migration of Constitutional Ideas (Cambridge, Cambridge University Press, 2007).

${ }^{60}$ Frank R Scott, Essays on the Constitution: Aspects of Canadian Law and Politics (Toronto, University of Toronto Press, 1977) ix.

${ }^{61}$ Benjamin L Berger, 'Children of Two Logics: A Way into Canadian Constitutional Culture' (2013) 11 ICON 319. I argue in this piece that the points at which the march of the logic of universal reason meets resistance in the particular are key junctures for understanding a country's constitutional culture because they are points at which the social and the political, which sit at the heart of every constitution no matter how modern and committed to universal reason, shine through.
} 
Forthcoming in Rex Adhar, ed., Research Handbook on Law and Religion (Northampton, Mass: Edward Elgar, 2018) (Pre-publication Version)

sweeps up and deals with some matters raised by religious difference. But freedom of religion and conscience and rights to religious equality have proven inadequate to the task of sorting through many of the most salient issues related to the assertive presence of public religion. In this way, the social facts and issues that have disrupted faith in the secular have also exposed the misleading nature of imagining that the vanguard and future of constitutionalism lies in the refinement and development of the universal logic of rights.

One could make this point by reference to recent experiences of constitutional design. For countries in which the influence and social salience of religion cannot be contained within a claim about secularism, the most complicated set of questions have been of the 'older' constitutional variety: what sources of law ought to be acknowledged? What ought to be the relationships between religious communities and political authority? ${ }^{62}$ Legal rights have been something of a side issue. But as it turns out, this lesson has also emerged out of established constitutional systems in which rights constitutionalism enjoys a prominent imaginative profile. Religion has forced such systems to confront questions drawn from that older, less liberally beguiling, model of constitutionalism.

Recent years have seen a fascinating institutionalist turn in the structure of debates about religious difference and constitutionalism. Confronted with the failure of individual rights of freedom of religion and conscience to adequately address entire dimensions of the interests and concerns of religious communities, claims have shifted away from such rights and towards arguments for the constitutional autonomy and privileges of religious institutions. ${ }^{63}$

\footnotetext{
${ }^{62}$ See Ran Hirschl, Constitutional Theocracy (Cambridge, MA, Harvard University Press, 2010).

${ }^{63}$ On this religious 'institutionalism', see Victor Manuel Muñiz-Fraticelli, The Structure of Pluralism: On the Authority of Associations (Oxford, Oxford University Press, 2014); Victor Muñiz-Fraticelli and Lawrence David, 'Religious Institutionalism in a Canadian Context' (2016) 52 Osgoode Hall LJ 1049; Micah Schwartzman, Chad Flanders \& Zoë Robinson (eds), The Rise of Corporate Religious Liberty (New York: Oxford University Press, 2016).
} 
Forthcoming in Rex Adhar, ed., Research Handbook on Law and Religion (Northampton, Mass: Edward Elgar, 2018) (Pre-publication Version)

One of the most striking examples in this respect is the US case of Hosanna-Tabor ${ }^{64}$ Returning from disability leave to find that the HosannaTabor Evangelical Lutheran Church had hired someone to replace her, a grade school teacher threatened to file suit pursuant to federal antidiscrimination laws. In reaction, the Church fired her, essentially for 'going to law'. When the case made its way to the courts, the Church argued that it enjoyed a 'ministerial exception', which meant that it was not subject to legal restrictions in its decisions about its religious leaders. The unanimous Supreme Court agreed, holding that this ministerial exception (an aspect of the Establishment Clause) exempted the Church from federal anti-discrimination protections. Chief Justice Roberts reasoned that ' $[t]$ he church must be free to choose those who will guide it on its way'. ${ }^{65}$ As Winnifred Sullivan has pointed out, this turn to 'the church' marks a significant moment in US constitutional law. ${ }^{66}$ It introduces an institutionalist dimension into the management of religious diversity in the United States, highlighting the entity of 'church' in the constitutional picture, and thereby focusing attention on the deeper relationship between religion and state and the legitimacy of constitutional authority over religion. Although integrated into the language of the First Amendment, this is not essentially a rights-based decision; it is more akin to a concordat regulating the relationship between the Vatican and the Italian State than an exercise in modern liberal constitutionalism.

In Canada, the recent Trinity Western case was an instance of this institutionalist turn in claims for religious freedom. ${ }^{67}$ Trinity Western University is an Evangelical Christian university that sought to establish the first private, 'faith-based' law school in Canada, a project aimed at affording a Canadian legal education in a 'Christian learning

\footnotetext{
${ }^{64}$ Hosanna-Tabor Evangelical Lutheran Church and School v Equal Employment Opportunity Commission, 565 US 171 (2012).

${ }^{65}$ Ibid, 196.

${ }^{66}$ Winnifred Fallers Sullivan, “"The Church”, The Immanent Frame, 31 January 2012 <https://tif.ssrc.org/2012/01/31/the-church/>.

${ }^{67}$ Law Society of British Columbia v Trinity Western University, 2018 SCC 32; Trinity Western University v Law Society of Upper Canada, 2018 SCC 33. For a more elaborated account of, and perspective on, the issues involved in this case, see the chapter by Janet Epp Buckingham in this Research Handbook, ch 20.
} 
Forthcoming in Rex Adhar, ed., Research Handbook on Law and Religion (Northampton, Mass: Edward Elgar, 2018) (Pre-publication Version)

community' ${ }^{68}$ The University requires all community members to sign a 'community covenant' that, among other things, prohibits sexual relationships between same-sex married couples. After charged public debate, two provincial law societies ultimately denied accreditation to the law school on the basis that the insistence on this code of conduct represents a form of institutional discrimination that contravenes legal guarantees of sexual equality. Drawing inspiration from a recent decision that represented the Supreme Court's most extensive recognition of the collective and social dimensions of freedom of religion, ${ }^{69}$ Trinity Western University responded to these denials by noting its institutional exemption from provincial human rights legislation and arguing that the law societies' decisions contravened the constitutional guarantee of religious freedom. Although there was also an individual claimant involved, the case was, at its heart, about a community's argument for political autonomy and institutional independence from public law norms. A majority of the Supreme Court found against Trinity Western and, though it essentially evaded this fundamental group rights question in its reasons, the decision generated a strong dissent and has fed ongoing scholarly and public controversy about the rights of religious communities vis-à-vis the state. As the case suggests, religious education is a particular flashpoint for this institutionalist or collectivist turn, with the complicated confluence of state and community interests making the set of issues involved in such cases irreducible to matters of individual rights. ${ }^{70}$ Religious education cases instead require reflection on and negotiation around the relationship

\footnotetext{
${ }^{68}$ Trinity Western University Proposed School of Law, 'Why Trinity Western University's School of Law?' Trinity Western University, <https://www.twu.ca/academics/schoolsfaculties/proposed-school-law>.

${ }^{69}$ Loyola High School v Quebec (Attorney General), 2015 SCC 12, which involved a Roman Catholic high school's argument that it should be free to teach the state-mandated Ethics and Religious Cultures curriculum from a Catholic perspective. A majority of the Court accepted that the collective dimensions of religious freedom prohibited the government from mandating how, as a Catholic institution, Loyola taught its own students about Catholicism. The minority reasons in the case went so far as to hold that the religious organization itself could enjoy the protection of freedom of religion.

${ }^{70}$ See, eg, Loyola and, in the UK, the JFS case.
} 
Forthcoming in Rex Adhar, ed., Research Handbook on Law and Religion (Northampton, Mass: Edward Elgar, 2018) (Pre-publication Version)

between religious communities and state authority. Such matters are inescapably local, historical, political, and particular. ${ }^{71}$

This renaissance of religious institutions and organizations as a matter for constitutional reflection is, thus, one example of how the facts associated with the unsettling of secularism have also destabilized the centrality of liberal rights constitutionalism in our accounts of modern constitutional law and practice.

Another such example revolves around questions of legal pluralism and sources of law. As religion demonstrates its energetic public presence, the normative dimension of religious life also shows itself, pluralizing law and putting questions around the recognition of religious legal orders and the authority and supremacy of state law firmly on the table. These are emphatically constitutional issues, but are not satisfyingly digestible as issues of rights constitutionalism.

The debate about 'sharia arbitration' in Ontario illustrates this well. In the fall of 2003, an organization called the Islamic Institute of Civil Justice proposed the use of arbitration tribunals that would resolve civil matters - particularly family law and inheritance disputes - through the application of principles of Islamic law. ${ }^{72}$ Although the law in Ontario had permitted private arbitration of disputes based on agreed-upon principles of law for almost 25 years, this proposal produced something of a 'moral panic' 73 and presented a substantial political question: should Islamic arbitration be permitted? Faced with strong opposition to the use of religious law to settle civil disputes, the Government of Ontario commissioned a report on the matter. Although the report came back recommending that, with the addition of certain safeguards, religious arbitration be permitted, the Government ultimately introduced

\footnotetext{
${ }^{71}$ In Canada, Adler v Ontario, [1996] 3 SCR 609, sharply dramatized the force of the historical and particular in matters of religious education, holding that the right to religious funding of Catholic schools, guaranteed in the 1867 constitution, however discriminatory and reflective of a state-sponsored privilege for one religion, was immune from attack through doctrines of religious freedom and equality, reflected in the 1982 Charter.

${ }^{72}$ I discuss this episode in the modern history of law and religion in Canada at greater length in Berger, Law's Religion.

${ }^{73}$ Sherene Razack, 'The "Sharia Law Debate" in Ontario: The Modernity/Premodernity Distinction in Legal Efforts to Protect Women from Culture' (2007) 15 Fem LS 3, 7.
} 
Forthcoming in Rex Adhar, ed., Research Handbook on Law and Religion (Northampton, Mass: Edward Elgar, 2018) (Pre-publication Version)

legislation purporting to ban all religious arbitration, with the Premier declaring that it would ensure that there was 'one law for all'.

The claim 'one law for all' is an innately constitutional claim. But a religiously diverse social world, which includes religions for which the legal dimension of the tradition is robust, means that this claim is at best aspirational, but certainly not descriptive. Negotiating this condition of legal pluralism emerges as an important dimension of modern constitutionalism. We see this in the transnational issue of whether to enforce religious divorce and family law arrangements through state courts. In Canada, that issue appeared in the case of Bruker $v$ Markovitz. ${ }^{74}$ The question was whether to award damages for a husband's refusal to provide a ghet. The packaging of this problem as one of religious freedom belied the real problematic, which was the relationship between 'secular' state and religious law. One sees the challenges surrounding that relationship played out fortissimo in places like Israel and India, where religious law has formal status in the state legal architecture, but they are intrinsic to the experience of religious pluralism. These issues flow from the basic question of how the state should relate to religious legal orders: a query that reaches back to the kinds of constitutional problems wrestled with in the wake of the Papal Revolution far more than it reaches forward into an era of the increasingly universal application of legal rights.

In his account of the challenges associated with the destabilization of political secularism, Tariq Modood argues that 'the novelty, which then has implications for Christians and secularists and to which they are reacting, is the appearance of an assertive multiculturalism which cannot be contained within a matrix of individual rights, conscience, religion [sic] freedom, and so on'.$^{75}$ Otherwise put, the character and implications of religious difference have overflowed folk accounts of secularism and, with it, have evaded the tools of rights constitutionalism. One way of understanding the nature of this overflowing is that the form of religiosity that was already 'bargained for' in a secularist account buttressed by individual rights - an internal, believed, private form of religion - no longer reflects our social lives. And as a result, we find ourselves presented

\footnotetext{
${ }^{74} 2007$ SCC 54.

${ }^{75}$ Modood, 'Western Europe’, 145.
} 
Forthcoming in Rex Adhar, ed., Research Handbook on Law and Religion (Northampton, Mass: Edward Elgar, 2018) (Pre-publication Version)

with questions whose character and demands disturb accounts of contemporary constitutionalism in which liberal rights are central.

\section{Legitimacy, Authority, and the Fading Salience of Sovereignty}

The capacity of religion to de-centre rights constitutionalism ultimately points to a third element of the constitutional common sense that is unsteadied by a social world that resists the claims of secularism: the fading salience of sovereignty.

The desire to find a ground for the authority and legitimacy of constitutional law not based in normative visions or identity claims has been, in large measure, motivated by an awareness of the challenges of religious difference. That awareness was an explicit impetus for Rawls' work and it drove the liberal political and legal theory that took its cue from him. ${ }^{76}$ Yet religion has ultimately proven to be a distinctively powerful device for showing frailties in the idea that an 'overlapping consensus' based on the fruits of public reason can be a satisfying basis for claims of legal and political authority. The assertive public force of religious difference has shown the shortcomings of the idea that there is a road that bypasses historical specificity, identity, ontology, and metaphysics, but that nevertheless delivers one to a satisfying account of constitutional legitimacy. The precise point of disruptive intervention has been to make deeply problematic the tenability of bracketing one's 'comprehensive doctrines' or larger metaphysical and normative conceptions of the good when engaging in public reasoning - a pivotal move for the success of such theories. As a phenomenological matter, religion has simply proven more unruly, more insistently 'political', and generally less containable than the demands for this move allow - the same realizations that have led to a disruption of faith in secularism.

As cases concerning issues like same-sex marriage, medicallyassisted suicide, and polygamy have accumulated, the idea that constitutional law can successfully base its claim of legitimacy and

\footnotetext{
${ }^{76}$ John Rawls, Political Liberalism (2nd edn, New York, Columbia University Press, 2005).
} 
Forthcoming in Rex Adhar, ed., Research Handbook on Law and Religion (Northampton, Mass: Edward Elgar, 2018) (Pre-publication Version)

authority on grounds of law's neutrality and on reason-based consensus begin to appear less convincing. Engagement with religious diversity has exposed constitutionalism as its own cultural enterprise, rich with senses of the subject, of authority, space, time, and value. ${ }^{77}$ Its categories for analysis and underlying commitments are partial, in both senses of the word. ${ }^{78}$ But if convergence and neutrality do not seem up to the task of underwriting state legal authority, we become aware of a group of legal subjects returning to those core questions of constitutional law and theory: 'Why does this bind me?', 'What is its authority over me?' And with this, I suggest, we are called to examine the abiding role of sovereignty in our contemporary constitutional lives.

For liberal constitutionalism, appeals to sovereignty have an antique and even embarrassing feel to them. As Kahn explains, '[c]laims of sovereignty reflect a community's understanding of itself as embodying a distinct set of meanings that are substantive not formal, realized at a particular historical moment, and limited to members'. ${ }^{79}$ The desire to base the character and cogency of law in universal reason - a leitmotif in this chapter - is in part an artefact of the ambition to release us from the burden of such illiberal claims. 'Traditionally, sovereignty was thought to precede ${ }^{l a w} ;{ }^{\prime} ; 0$ the hope of liberal constitutional thought is that, through the universality of reason and rights, 'law is to be freed from sovereignty' ${ }^{81}$ But with the conventional liberal ground for legitimacy unsettled by religious diversity, claims for the authority of law based in sovereignty the popular sovereignty of 'who we are' and 'what we are', as Kahn's explanation reflects - seem to re-emerge, rushing in to fill the vacuum. Sovereignty reappears, actively shaping our legal debates and practices; it

\footnotetext{
${ }^{77}$ I have developed this idea at length in Berger, Law's Religion.

${ }^{78}$ See ibid, 62-104.

${ }^{79}$ Paul W Kahn, Putting Liberalism in Its Place (Princeton, Princeton University Press, 2004), 11.

${ }^{80}$ Ibid.

${ }^{81}$ Ibid, 12.
} 
Forthcoming in Rex Adhar, ed., Research Handbook on Law and Religion (Northampton, Mass: Edward Elgar, 2018) (Pre-publication Version)

is no longer simply 'latent in the constitutional state' 82 or 'only an abstract subject for the ascription of acts of public authority'.$^{83}$

This is one way of understanding the 'Islamic headscarf' controversy in France, centred around the 2003 Stasi Commission report. Talal Asad tells the story in just this way. He argues that one can look past the abstract arguments about laïcité to see deeper concerns about the identity of the French republic and the sovereign character of the state. ${ }^{84}$ What troubled the state about the 'appearance' of the Islamic headscarf was not the garment itself, but 'the actor's will to display it', 85 which seemed to symbolize a resistance to the universal character of French republican identity and the sovereignty of the state built on that identity. The authority of the resulting legal regulation of the headscarf was not based on consensus or reason, but on assertions of sovereignty and the authority of the state. ${ }^{86}$ This leads Asad to the provocative claim 'that the French secular state today abides in a sense by the cuius region eius religio principle': 87 whose realm, his religion. Liberal constitutionalism does not have the tools to reckon with such a governing principle, utterly saturated as it is by sovereignty. Nor, as a result, does it have a convincing account for this episode, centrally concerned as it was with the meaning of symbols, history, and claims about national identity. The authority and legitimacy of state law's response to this 'veil affair' were not and could not be found in overlapping consensus or neutrality; instead, however

\footnotetext{
${ }^{82}$ Dieter Grimm, Sovereignty: The Origin and Future of a Political and Legal Concept (New York, Columbia University Press, 2015) 72. Grimm does not suggest that sovereignty has no role in a modern constitutional state; rather, his claim is that, apart from its relevance to federalism issues and international questions (what he calls 'external sovereignty'), the nature of modern constitutionalism 'has made the sovereign invisible (ibid, 73). My argument is that the unsettling of secularism brings the sovereign back into our field of vision.

83 Ibid, 73.

${ }^{84}$ Asad, Formations of the Secular.

85 Ibid, 97.

${ }^{86}$ Asad explains that ' $[\mathrm{t}]$ he banning of the veil as a sign can therefore be seen as an exercise in sovereign power, an attempt by a centralized state to dominate public space as the space of particular signs', ibid, 101.

${ }^{87}$ Ibid, 94.
} 
Forthcoming in Rex Adhar, ed., Research Handbook on Law and Religion (Northampton, Mass: Edward Elgar, 2018) (Pre-publication Version)

embarrassing to a liberal constitutional order, it was to be found in claims of sovereignty.

In Canada, the continued salience of sovereignty to contemporary constitutionalism can be seen in a variety of examples involving legal and political encounters with religious difference and the reckoning with the instability of the secular. One potent example arises from an ongoing controversy about the nature and demands of secularism in Quebec, a controversy that has contours very similar to the French episode that so interested Asad. In the fall of 2013, a minority sovereigntist Parti Québécois (PQ) government introduced Bill 60, a bill referred to as the 'Charter of Québec Values' or, in much of the debate that ensued, the 'Charter of Secularism'. ${ }^{88}$ This Bill declared the religious neutrality and secular nature of the state and proposed a contentious prohibition on employees of public bodies from wearing 'ostentatious' or conspicuous religious symbols, such as turbans, kippot, and headscarves. This proposed ban charted out a form of secularism for Québec quite at odds with Canadian multiculturalism, and most agreed that this proposal was unconstitutional as measured against the rights protections in the Canadian Charter of Rights and Freedoms. The best interpretation of this move, however, was as part of a continuous constitutional story in Canada whereby claims about Quebec's distinctive status in Canadian federalism and its political independence are based, in part, on a very different relationship with religion than is found elsewhere in Canada. ${ }^{89}$ In the early constitutional life of the country, this unique relationship was Quebec's Roman Catholic identity, in contrast to the Protestantism of English Canada, and this matured into its rejection of multiculturalism and embrace of a French-style laïcité as its interpretation of the demands of secularism. Throughout, the structural relationship has remained the same: distinctiveness within Canadian federalism is asserted by means of articulating a relationship with religious difference. Such claims, so thick

\footnotetext{
${ }^{88}$ Bill 60, Charter affirming the values of state secularism and religious neutrality and of equality between women and men, and providing a framework for accommodation requests, 1st Sess, 40th Leg, Québec, 2013.

${ }^{89}$ I explore this interpretation in greater detail in Benjamin L Berger, 'Faith in Sovereignty: Religion and Secularism in the Politics of Canadian Federalism' (2014) 35 Istituzioni del Federalismo 939.
} 
Forthcoming in Rex Adhar, ed., Research Handbook on Law and Religion (Northampton, Mass: Edward Elgar, 2018) (Pre-publication Version)

with ideas of the identity of the political community, are difficult to digest within accounts of political and legal liberalism. Rather, they are consonant with Kahn's description of sovereignty claims - reflective of 'a community's understanding of itself as embodying a distinct set of meanings that are substantive not formal, realized at a particular historical moment, and limited to members' ${ }^{90}$

Many of the examples explored in the previous section similarly push us into the arms of an account of the authority and legitimacy of constitutional law not based on convergence or reasonable consensus, but on assertions of sovereignty. There is a connection between the decentring of rights constitutionalism and a renewed awareness of the abiding salience of claims of sovereignty in our constitutional lives. As the former shifts, we gain a better line of sight on the latter. For example, the questions of legal pluralism raised by religious difference ultimately call on courts and other legal actors to account for the relationship of authority between state law and religious legal orders, a relationship that invites appeals to sovereignty. This was clear in Premier McGuinty's claim of 'one law for all' as a response to the sharia arbitration debate: 'one law for all' is really 'one law for all of $u s^{\prime}$, an assertion that draws out the relations of legal authority, group membership, and popular sovereignty. Similarly, the negotiation of the relationship between religious communities and state/constitutional authority required by the institutionalist turn raises questions of a character that do not appear resolvable by resort to claims for constitutional authority based on overlapping consensus or rational neutrality. The relationship between church and state, the authority of religious law versus that of constitutional law: these are irreducibly matters involving questions of sovereignty and call for responses drawn from that register.

A powerful final example of the way in which claims about religion have a distinctive capacity to expose the work that sovereignty continues to do in the practice and structure of constitutional law in Canada comes from a recent freedom of religion claim involving Indigenous religion. Of course, sovereignty's continued role in questions of constitutional justice is conspicuous in all issues that involve Indigenous peoples. Claims for

\footnotetext{
${ }^{90}$ Kahn, Putting Liberalism in Its Place, 11.
} 
Forthcoming in Rex Adhar, ed., Research Handbook on Law and Religion (Northampton, Mass: Edward Elgar, 2018) (Pre-publication Version)

Aboriginal rights, title over land, or the enforcement of historical treaties all manifestly take place on a terrain of contested sovereignty. What was unique about the Ktunaxa Nation ${ }^{91}$ case was that it involved a claim for the protection of Indigenous religion through the general guarantee of freedom of religion pursuant to s 2(a) of the Charter. The Ktunaxa asserted that the government's approval of a large resort development project in a region of British Columbia called the Jumbo Valley or, for the Ktunaxa, Qat'muk, offended their religious freedom. The Ktunaxa believe that the valley is the home of the Grizzly Bear Spirit, a figure of spiritual significance to the Ktunaxa, and that the construction of permanent accommodations would drive the Grizzly Bear Spirit from Qat'muk. Proceeding with the development would, thus, 'irrevocably impair their religious beliefs and practices'. ${ }^{92}$ The Court euphemistically characterizes this as 'a novel claim' ${ }^{93}$ It was, in fact, a claim with radically subversive potential. Given the connection between Indigenous religion and the land, ${ }^{94}$ and the wide definition of religious freedom in Canadian jurisprudence to that point, this claim had profoundly disruptive potential for the Crown use and control of land and its resources.

The Supreme Court of Canada unanimously dismissed the Ktunaxa's claim, and did so in a way that points to the energetic work that state sovereignty claims continue to do in shaping constitutional justice. Chief Justice McLachlin and Justice Rowe, writing for a majority of the Court, conclude that the Ktunaxa's claim falls outside the scope of freedom of religion because they were seeking to protect not their beliefs and practices, but rather the Grizzly Bear Spirit itself. The majority explains that 'the Charter protects the freedom to worship, but does not protect the spiritual focal point of worship'.$^{95}$ But of course, unlike the other traditions with which the Court is accustomed in its freedom of religion

\footnotetext{
${ }^{91}$ Ktunaxa Nation v British Columbia (Forests, Lands and Natural Resource Operations), 2017 SCC 54.

${ }^{92}$ Ibid, [6].

${ }^{93}$ Ibid, [70].

${ }^{94}$ John Borrows, Canada's Indigenous Constitution (Toronto, University of Toronto Press, 2010) 239.

${ }^{95}$ Ktunaxa Nation, [71].
} 
Forthcoming in Rex Adhar, ed., Research Handbook on Law and Religion (Northampton, Mass: Edward Elgar, 2018) (Pre-publication Version)

jurisprudence, the 'spiritual focal point of worship' for the Ktunaxa is vulnerable to state interference: the Grizzly Bear Spirit is tied to the land. Justice Moldaver, in separate reasons, rightly points to this distinguishing feature, explaining that '[f]or Indigenous religions, state action that impacts land can therefore sever the connection to the divine, rendering beliefs and practices devoid of their spiritual significance' ${ }^{96}$ The majority's approach, therefore, 'risks foreclosing the protections of s. 2(a) of the Charter to substantial elements of Indigenous religious traditions' ${ }^{\prime 77}$ And yet, though he would have therefore found that the approval infringed the Ktunaxa's freedom of religion, Justice Moldaver justified the government's decision as 'reasonable in the circumstances'.$^{98}$ His reasons expose the extent to which the result in this case is underwritten by legitimizing $a$ priori sovereignty claims. To accede to the Ktunaxa's claim would allow them 'to veto development over the land' ${ }^{99}$ and 'would effectively transfer the public's control of the use of over fifty square kilometres of land to the Ktunaxa'. ${ }^{100}$ Justice Moldaver explains:

This placed the Minister in a difficult, if not impossible, position. He determined that if he granted the power of exclusion to the Ktunaxa, this would significantly hamper, if not prevent, him from fulfilling his statutory objectives: to administer Crown land and to dispose of it in the public interest. ${ }^{101}$

The pivotal phrase here is 'Crown land'. Is Qat'muk Crown land to be disposed of in the public interest? That question - the status of that land and the sovereignty claim over it - is the irreducible political core of such disputes between the state and Indigenous peoples. Although this is somewhat less obvious in the majority's decision owing to the choice to treat this as a matter of the scope of the right rather than one of justification,

\footnotetext{
${ }^{96}$ Ibid, [127].

${ }^{97}$ Ibid, [131].

${ }^{98}$ Ibid, [155].

${ }^{99}$ Ibid, [150].

${ }^{100}$ Ibid, [152].

${ }^{101}$ Ibid, [154].
} 
Forthcoming in Rex Adhar, ed., Research Handbook on Law and Religion (Northampton, Mass: Edward Elgar, 2018) (Pre-publication Version)

the effacing of the link between land and religion evidences similar concerns and preoccupations. A tantalizing tell comes in the majority's initial description of the facts. The majority explains that the area in dispute 'is located in a Canadian valley in the northwestern part of the larger Ktunaxa territory'. ${ }^{102}$ Is it a 'Canadian valley' or is it part of 'Ktunaxa territory'? The shearing forces within this facially anodyne statement are the forces exerted by sovereignty claims. Imaginatively, both decisions begin from an assertion of state sovereignty over the land; they proceed from, are shaped by, and ultimately return to that imaginative foundation.

Each of these examples demonstrates the way in which a public and political pertinence of religion that is incommensurable with folk claims about political secularism disrupts a treasured conceit of liberal constitutional thought and practice: that the work of constitutional justice can be done, and can be understood, without recourse to the kinds of claims about historical particularity, community identity, and - yes - metaphysics and ontology, associated with assertions of sovereign authority. They challenge accounts of modern constitutionalism premised on 'the minor importance of the concept of sovereignty to the interpretation and application of constitutions' ${ }^{\prime}{ }^{103}$ In each example, the work of contending with religion reveals that more constitutional justice than we are comfortable admitting is shaped by conceptions and claims of sovereignty. As the picture of the social world painted by a simple story of secularism becomes more complicated and less plausible, so too does the wish for a constitutionalism that is 'freed from sovereignty'. 104

\section{CONCLUSION}

Liberal constitutional theory and practice has, I have argued, proceeded on an unacknowledged faith in a certain conception of the secular that is reasonably descriptive of the place of religion in contemporary society, and where not descriptive, at least affords a

\footnotetext{
${ }^{102}$ Ibid, [3].

${ }^{103}$ Grimm, Sovereignty, 71.

${ }^{104}$ Kahn, Putting Liberalism in Its Place, 12.
} 
Forthcoming in Rex Adhar, ed., Research Handbook on Law and Religion (Northampton, Mass: Edward Elgar, 2018) (Pre-publication Version)

reasonably coherent regulative ideal. Yet the facts surrounding the abiding public presence and assertiveness of religion in our social and political lives resist that description, and the concept of the secular has proven too complex, variable, and untidy to offer stable footing. The faith thus disrupted, certain features of our constitutional theory and practice themselves become unsettled. Proportionality seems troubled both in its capacity to carry off the task assigned to it and as a description of the central feature of modern constitutional adjudication, which, in matters of religion, seems to be a practice thick with symbolic interpretation informed by claims about identity and history. Rights constitutionalism assumes a more modest position within the features of modern constitutional life, with structural issues that wrestle with the presence of multiple salient sources of normative ordering coming into our field of view. And confidence in the fading salience of sovereignty as a player in the structure of constitutional authority and legitimacy seems ill placed.

Philip Selznick once described the sociology of law 'as an attempt to marshal what we know about the natural elements of social life and to bring that knowledge to bear on a consciously sustained enterprise, governed by special objectives and ideals'. 105 Martin Krygier explains that in describing the features of social life as 'natural', Selznick meant to capture the idea that '[s]ociety is a natural, if naturally variable, response to the character and coincidence of human nature, needs, strivings, and particular circumstances'. ${ }^{106}$ Approached as 'a consciously sustained enterprise, governed by special objectives and ideals', law, for Selznick, 'is a kind of activity carried on by living [people] in living institutions, subject to all the external pressures and constraints, and all the inner sources of recalcitrance, that frustrate ideal ends'. 107 Selznick's particular understanding of the task of legal sociology was, thus, to bring the ideals, objectives, and project of law into conversation with what we know about the real circumstances, needs, and character of social life.

\footnotetext{
${ }^{105}$ Philip Selznick, 'Sociology of Law' in Robert King Merton et al. (eds), Sociology Today: Problems and Prospects (New York, Basic Books, 1959) 116.

${ }^{106}$ Martin Krygier, Philip Selznick: Ideals in the World (Stanford, Stanford Law Books, 2012) 108.

${ }^{107}$ Philip Selznick, 'Review of The Morality of Law' (1965) 30 Am Soc Rev 947, 947.
} 
Forthcoming in Rex Adhar, ed., Research Handbook on Law and Religion (Northampton, Mass: Edward Elgar, 2018) (Pre-publication Version)

This chapter participates in a genre of constitutional reflection that is inspired by a similar sociological instinct. It is a genre that seeks to hold our constitutional practices, theories, and common sense to the discipline of actually accounting for the social world with which constitutions interact. James Tully does this, turning his eyes to the global south and the lived experiences of imperialism and colonialism, arguing for new ways of theorizing and practicing constitutionalism. ${ }^{108}$ Similarly, John Borrows expertly draws out the 'needs, strivings, and particular circumstances' of Indigenous peoples to point to the inadequacy of prevailing constitutional theories and practices, and to urge a new understanding and orientation to our constitutional lives. 109

This chapter has sought to do something of the same character, asking what we learn when we marshal what we know about the complexity and untidiness of the role of religion in modern society and bring that knowledge to bear on the enterprise of liberal constitutionalism in a social world that resists any straightforward application of the label 'secular'.

108 James Tully, Strange Multiplicity: Constitutionalism in an Age of Diversity (Cambridge, Cambridge University Press, 1995); James Tully, Public Philosophy in a New Key: Volume 1, Democracy and Civic Freedom (Cambridge, Cambridge University Press, 2009); James Tully, Public Philosophy in a New Key: Volume 2, Imperialism and Civic Freedom (Cambridge, Cambridge University Press, 2009).

${ }^{109}$ Borrows, Canada's Indigenous Constitution; John Borrows, Drawing Out Law: A Spirit's Guide (Toronto, University of Toronto Press, 2010). 